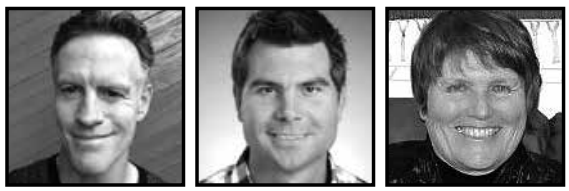

\title{
Commentary
}

\section{Shifting Teacher Education From "Skilling Up" to Sustaining Beginning Teachers}

\author{
C. Aiden Downey, Lee Schaefer, and D. Jean Clandinin
}

\begin{abstract}
Early career teacher attrition is a serious concern. While the problem is usually seen as one of skilling up new teachers, based on a two-year study with 50 early career teachers, we suggest the importance of attending to what sustains them. While beginning teachers need knowledge and skills, they also need places that allow them to continue to live out their stories to live by, identity stories that encompass both who they are and are becoming as teachers and as people. Attending to stories to live by means we attend to teacher knowledge, knowledge shaped in, and expressed in, both personal and professional knowledge landscapes.
\end{abstract}

1 uring a meeting with a variety of education stakeholders about early career teacher attrition, a policymaker stated, "We need to skill them up quickly." Like many others, it seemed he understood the problem of new teachers leaving teaching as a question of their competency: stemming the flow of teacher leavers hinged on getting beginning teachers the skills and knowledge they needed quickly. The discussion in the meeting moved on but "skill them up" and what it meant about how teachers learn to teach lingered with us as we continued to work on a research project on early career teacher attrition. Now, after talking with more than 50 early career teachers, some of whom were still teaching, some who had left, and some who did not accept teaching positions in schools, the project is complete. However, what we learned from the research participants leaves us even more puzzled, and troubled, by the phrase, "skill them up." 
Our take on learning to teach is a narrative one, one that is deeply situated in a narrative conception of teacher knowledge and, thus, a narrative view of learning to teach from living out stories, telling stories of the living, and engaging in inquiry processes into the stories that we each have lived and told and continue to live and tell. Learning to teach, composing what we term "teacher knowledge," is a deeply experiential process. We contrast what we call teacher knowledge with "knowledge for teachers"; the knowledge that others decide teachers need in order to be able to teach (Connelly \& Clandinin, 2007). Knowledge for teachers is what we think the policymaker in the meeting was referring to as he spoke of skilling up beginning teachers. We do not deny the importance of knowledge for teachers. However, what we learned from study participants indicated that it is by no means the only kind of knowledge that new teachers have or need. As we attended to what the teachers told us, we learned it is also not the most important kind of knowledge to which we need to attend if we are to sustain beginning teachers in teaching.

As part of our overall study, we engaged in a narrative inquiry with six teachers who left teaching within their first five years (Clandinin, Schaefer, \& Downey, 2014). The stories they told of their lives taught us much. We learned with them that we needed to attend closely to their stories to live by (Connelly \& Clandinin, 1999). Using a narrative understanding of knowledge as embodied and contextual, we understand stories to live by as the stories that brought them to teaching. Teachers' stories to live by are "shaped by such matters as secret teachers' stories, sacred stories of schooling and teachers' cover stories" (p. 4). The concept of stories to live by allows us to link personal practical knowledge and the knowledge contexts or landscapes in which lives are lived and composed. Participants' stories to live by helped us see that learning to teach did not begin when they attended university teacher education programs, and became aware of knowledge for teachers. Their teacher education started early in what we are now calling their personal knowledge landscapes (Clandinin, Schaefer, \& Downey, 2014). As they composed their lives in their early years, prior to becoming teachers, they began to compose their personal practical knowledge and their stories to live by. These are the stories that shape individual lives, the stories that shape who we are and are becoming. As the early career teachers entered into what we call their professional knowledge landscapes, they entered living and telling their stories to live by and enacting their personal practical knowledge that is neither "modeled on theoretical knowledge" (Clandinin, 1986, p. 177) nor seen as valuable to teachers. As Clandinin wrote almost 30 years ago, "When theoretical knowledge is adopted as a model, personal practical knowledge is seen as different and, consequently, inferior. I see knowledge as embodied in persons, embedded in culture and based on narrative unity" (p. 177). 
It was not that the early career teachers did not need knowledge for teachers. They valued learning how to organize lesson plans, draw on disciplinary knowledge, and manage their classrooms, learning that occurred in their university classes, teaching practica, and in their mentoring and induction programs. However, they helped us see that the process of becoming a teacher is a means to live out who they are, and are becoming, not an end in and of itself. As we talked with them, they showed us their stories to live by fueled their desire to become teachers. Teaching became a way to try to live out and sustain their stories to live by. Through listening closely and noticing resonant threads in their stories lived and told, we awakened to how participants continued to live out their stories to live by shaped in those early personal knowledge landscapes and embodied in their personal practical knowledge. They came to teaching with intentions to continue to live out their stories to live by. When they could not sustain their stories in the professional knowledge landscapes, their stories to live by shifted to stories to leave by (Schaefer, Downey, \& Clandinin, 2014).

In listening closely to teachers over time and in relationships forged over multiple conversations, our framing of how we understood their experiences began to shift. No longer did we see them as teachers who left, although they had left teaching. We saw them as people in the midst of negotiating and living lives, as always in the midst of becoming. As we began to see them as people who were teaching rather than only as teachers, we came to understand their teacher knowledge as part of their larger lives. Spending time with them out of school and well after they were no longer teaching in schools allowed us to see that while teaching was an important part of their lives, it was only part of the larger and unfolding whole of their lives. Seeing them as people composing lives within the place called school and in relationship with children, other staff members, children's families, subject matter knowledge, and professional responsibilities, allowed us to see them differently, to hear their stories in a different way, from a shifted vantage point. We saw them as composing their lives in two knowledge landscapes: the personal and the professional.

Gradually we began to hear their struggles of becoming, struggles that were not only about becoming teachers, but were also struggles about how to express their stories to live by and become the people they imagined they would be. In each participant's stories to live by we heard them tell that becoming a particular kind of teacher was interwoven with becoming a particular kind of person. These imaginings, fostered in personal knowledge landscapes, were intimately intertwined with their stories to live by, stories they embodied as they entered into their professional knowledge landscape. We were struck by how silenced their stories of experience were. They found themselves without a space and without a language for talking about what was happening to them 
as they moved into and then out of teaching. We believe part of the silencing occurs because what we call teacher knowledge is often not valued as knowledge in schools. What is valued is knowledge for teaching; the codified abstract knowledge of teaching that is often studied by researchers, taught to teachers, and discussed by policymakers such as the one we quoted at the outset (Connelly \& Clandinin, 2007).

From our experiences as teacher educators, we worry about the lack of space in our programs for students to talk about their knowledge, the knowledge that brought them to teaching. We worry that in our hurry to skill up teachers that we disregard and dismiss the very thing that will sustain them in the professional knowledge landscape, that is, their personal practical knowledge shaped by, and in, their stories to live by. While we understand how knowledge for teachers may help to retain them in schools, we assert that their teacher knowledge, the personal practical knowledge composed in the living of a life that often gets discounted in teacher education programs, may be of more value in sustaining them as teachers.

\section{What Are We Saying About Teacher Education?}

What we know from our own lives as people who taught in schools and from the stories of the experiences of the six participants, is that the "personal" seems to have no place in the professional knowledge landscape. We may be able to live out this personal knowledge in secret places, behind closed doors or even perhaps in staff rooms. However, usually the personal does not find a space in classrooms and schools. The imagined stories of working alongside students are left by the wayside as we move into the expert role of providing knowledge to students and preparing them for achievement tests. We learn to hide our personal knowledge.

Perhaps this is because, in a nutshell, teacher education programs aim to turn people into teachers. In teacher education classrooms we often hear the importance of moving from a "student identity" to a "teaching identity." The notion of teaching as a profession creates a barrier between the person and the professional. The professional is defined by the ability to separate the professional and the personal and draw on professional knowledge as the basis for one's work. While there are certain advantages to separating the personal and professional, we wonder if this separation might be problematic in the teaching profession. Good teachers are supposed to be so personally committed to their profession and students that the professional consumes the personal. It seems that their teacher identity should colonize the person to the point where the person is barely visible. We expect people who become teachers to stop being people. 
From our conversations with the early career teachers, we understand the importance of acknowledging the complexity of learning to teach as a life-making process that occurs in personal knowledge landscapes that shape our stories to live by and personal practical knowledge. We need to make more explicit to those we teach in our teacher education programs that we each continue to live in our personal knowledge landscapes as we enter professional knowledge landscapes. We need to find ways to allow beginning teachers to make visible the ways that their knowledge is rooted in their personal knowledge landscape. This is not to valorize or celebrate all of the knowledge that prospective teachers embody. We realize that there is much that each of us needs to carefully attend to as we work with the diverse children and families in our rapidly changing schools and classrooms. It is, rather, to begin to make the complexities of this knowledge visible, to open it to inquiries that lead us to question what we know, how we know, and what we need in order to sustain ourselves in living our lives as people who are teaching. This is not work that we can undertake lightly, easily, or quickly. It is difficult work that asks each of us to attend carefully to questions of teacher knowledge. Helping people in our teacher education classrooms learn to inquire into their knowledge and learn to sustain themselves as teachers is up to us.

\section{References}

Clandinin, D. J. (1986). Classroom practice: Teacher images in action. London: Falmer Press.

Clandinin, D. J., Schaefer, L., \& Downey, C.A. (2014). Narrative conceptions of knowledge: Toward new understandings of teacher attrition. London: Emerald Press.

Connelly, F. M., \& Clandinin, D. J. (1999). Shaping a professional identity: Stories of educational practice. New York: Teachers College Press.
Connelly, F. M., \& Clandinin, D. J. (2007). Teacher education - A question of teacher knowledge. In J. Freeman-Moir \& A. Scott (Eds.), Shaping the future: Critical essays on teacher education. Rotterdam: Sense Publishers.

Schaefer, L. Clandinin, D. J, \& Downey, C.A. (2014). Shifting from stories to live by to stories to leave by: Early career teacher attrition. Teacher Education Quarterly, Winter, 9-27. 


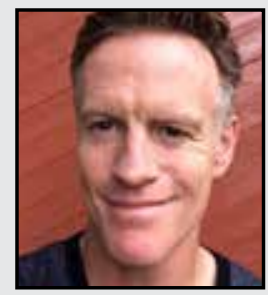

C. Aiden Downey is the Director of Undergraduate Education at the Division of Educational Studies at Emory University. He also co-founded The Workshop School (http:// www.workshopschool.org/), an innovative public high school in Philadelphia. A former public high school teacher, he is interested in how teachers, and in particular those teaching in urban contexts, make sense of their work, lives, and selves.

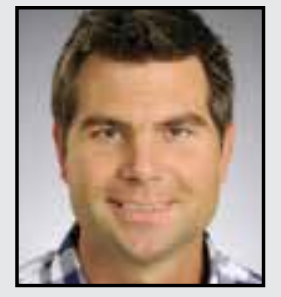

Lee Schaefer is an Assistant Professor at the University of Regina in the Faculty of Education. He currently teaches undergraduate curriculum and instruction courses as well as graduate courses focused on using narrative inquiry as a research methodology. Over the past five years his research focus has been on early career teacher attrition and early career teachers. Aiden, Lee, and Jean have a book titled, Narrative Conceptions of Knowledge: Towards Understanding Teacher Attrition, that will be released in the upcoming year.

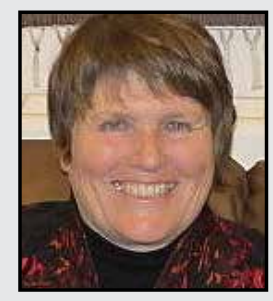

D. Jean Clandinin is Professor and Director, Centre for Research for Teacher Education and Development, University of Alberta. A former teacher, counselor, and psychologist, she and Michael Connelly co-authored four books including Narrative Inquiry (Jossey-Bass, 2000). Jean also authored Engaging in Narrative Inquiry (LeftCoast Press, 2013) and co-authored Composing Diverse Identities: Narrative Inquiries Into the Interwoven Lives of Children and Teachers (Routledge, 2006), Places of Curriculum Making: Children's Lives in Motion (Emerald, 2011) and Composing Lives in Transition: A Narrative Inquiry Into the Lives of Early School Leavers (Emerald, 2013). She has won awards from AERA, University of Alberta, and Canadian Education Association. 